DOI: https://doi.org/10.31933/dijms.v2i3

Received: 3 November 2020, Revised: 15 December 2020, Publish: 24 Jauary 2021

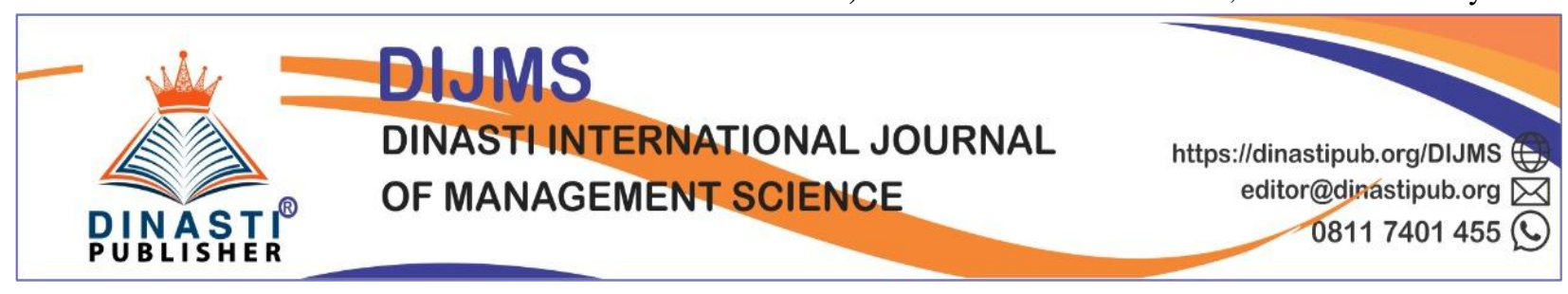

\title{
ANALYSIS OF THE EFFECT OF ELECTRONIC CUSTOMER RELATIONSHIP MANAGEMENT (E-CRM) AND BRAND TRUST ON CUSTOMER SATISFACTION AND LOYALTY IN PIXY COSMETIC PRODUCTS
}

\author{
Tasya Nandya ${ }^{1}$, Dudi Permana ${ }^{2}$ \\ ${ }^{1)}$ Magister of Management, Universitas Mercubuana Jakarta, Indonesia, \\ bussiness.tasyanandyablog@gmail.com \\ ${ }^{2)}$ Lecturer of Postgraduate, Universitas Mercubuana Jakarta, Indonesia, dudi.permana@mercubuana.ac.id
}

Correspondence to : Dudi Permana

Abstract: The purpose of this study was to study the Analysis of the Effects Electronic Customer Relationship Management (E-CRM) and Brand Trust to Customer Satisfaction and Loyalty to Pixy Cosmetic Brand. by measuring indicators that influence the variables of E-CRM, Brand Trust, Customer Satisfaction and Loyalty. This research uses descriptive research design using survey methods. Sampling uses certain criteria where respondents have known Pixy Cosmetics products from Key Opinion Leader and have bought Pixy Cosmetic Products via E-commerce and Offline store as well, at least 1 time in as a sampling technique. This study discusses using the structural equation model (structural equation modeling) - Lisrel to discuss the significance of the overall model relationship and predetermined pathways. The findings show that the E-CRM variable is positive and significant towards Customer Satisfaction, the Brand Trust is positive and significant towards Customer Satisfaction, and Customer Satisfaction is positive and significant towards the Loyalty.

Keywords: E-CRM, Brand Trust, Customer Satisfaction, Loyalty

\section{INTRODUCTION}

Indonesia is a market with attractive e-commerce growth from year to year. Since 2014, based on Euromonitor data, online sales in Indonesia have reached US \$ 1.1 billion. Based on = Central Statistics Agency (BPS) data also stated that the Indonesian e-commerce industry in the last 10 years has increased by 17 percent with a total number of e-commerce businesses reaching 26.2 million units. 
In 2018, e-commerce in Indonesia has experienced very rapid growth, and it is estimated that it will continue to increase as the number of entrepreneurs and entrepreneurs of Micro, Small and Medium Enterprises (MSMEs) in Indonesia grow. Over the past 4 years, e-commerce in Indonesia has increased by up to 500 percent. The latest research by Google and including in the e-Conomy SEA 2018 report shows that Indonesia's digital economy this year has reached US \$ 27 billion or around IDR 391 trillion. This figure makes Indonesia's digital economic transactions ranked first for the Southeast Asia region with a contribution of 49 percent.

As reported by TechinAsia.com, the management consulting firm McKinsey \& Company in August 2018 released research results regarding the current status of the Indonesian ecommerce industry, as well as projections of its development over the next few years. Currently, the e-commerce industry has had a positive impact on Indonesian employment with an estimated 4 million workers connected to this ecosystem. These new jobs include those that have emerged to support e-commerce activities, such as programming or logistics positions in e-tailing companies and existing jobs that have been renewed by e-commerce developments, such as MSME managers moving from offline to online businesses. producers and distributors, consumer shopping trends will also experience various changes. So far, the ease of transacting and choosing products has driven the number of online consumers projected to increase by around $25 \%$ annually and will reach 65 million people by 2022 . The increase in popularity of online shopping is also related to the relatively cheaper costs compared to shopping for similar products offline. For example, online consumers in Java, especially urban areas, save 4-14\% on average compared to offline shopping. This is because high operating costs make the prices of offline goods more expensive, while a comprehensive distribution network makes online shipping costs cheaper.

This trend change certainly encourages the development of Customer Relationship Management or CRM into E-CRM. The Indonesian economy in the era of globalization was built through the empowerment of micro, small and medium enterprises (MSMEs) and cooperatives. The Electronic Customer Relationship Management (E-CRM) system is customer management for e-Business that must deal with the complexities of attractive management for customers and business partners in a variety of media, including online and offline media, personal contact, and other electronic communication media. (Kalakota and Robinson, 2004: 148-149).

Social media makes it easier for consumers to find information and find their needs. So that the existence of social media makes it easier for consumers to get their needs and wants. Apart from consumers, it is also easier for business actors to get relationships with customers, brand trust from consumers. With a relationship with customers or E-CRM and brand trust, consumer purchasing decisions will increase. This is none other than the role of the development of social media that has developed over the last 5 years. YouTube takes first place with a percentage of 43 percent, Facebook, WhatsApp, and Instagram trailing in second to fourth place respectively. YouTube is a website that facilitates users to share the videos they have or are limited to enjoying various video clips uploaded by various parties. There are various kinds of videos that can be uploaded to this site, such as music videos from certain musicians, short films, television films, film trailers, educational videos, video blogs belonging to vloggers, video tutorials on various activities, and many more. YouTube gets its income from advertisements that are displayed before YouTube videos are played. These ads are called Google AdSense, a 
program that offers payments based on the rate at which a video is played. In February 2017, it was noted that a video with a total duration of 400 hours was uploaded on Youtube every minute and a total of one billion hours of YouTube content watched by people every day. This certainly has an impact on the increasing interest of the millennial generation to create a YouTube channel so they can earn additional income, as well as making the profession "YouTuber" as their main income. The increased interest and diversity in these audiences are very beneficial for content creators from Indonesia. The number of Indonesian creators who have earned the Gold Play Button (an award that YouTube gives to creators with more than one million subscribers) has increased rapidly in recent years, indicating the increasing number of Indonesian netizens using YouTube. Also, the quality of content made by Indonesian creators has increased so that it has succeeded in attracting a wider audience.

According to Google, more and more brands are realizing the potential of YouTube to attract consumers through creative messaging. The ad video successfully grabbed the audience's attention through:

1. Innovations in telling stories through advertising, such as serials,

2. Take advantage of moments and everyday life of customers, such as holidays,

3. The use of celebrity figures, and

4. Experiment with the duration that is most effective for conveying the message.

One of the YouTubers whose channel has grown rapidly in a short period is Ririeprams, which focuses on beauty content and family blog videos. Along with the rapid development of the Ririeprams YouTube Channel, more and more beauty brands are inviting Ririeprams to collaborate with the brand. With the hope of increasing engagement and brand awareness for consumers to buy goods from brands that are being promoted by Ririeprams. One of the famous local beauty brands is Pixy. With this phenomenon, the researchers conducted a preliminary survey related to E-CRM, Brand Trust dan Customer Satisfaction.

Table 1. Results of Preliminary Study on Purchasing Decision for Pixy Cosmetic Product

\begin{tabular}{|c|c|c|c|c|}
\hline \multirow{2}{*}{ No } & \multirow{2}{*}{ Indicator } & \multicolumn{2}{|c|}{ Choices } & \multirow{2}{*}{$\mathbf{N}$} \\
\hline & & Yes & No & \\
\hline 1 & $\begin{array}{l}\text { Pixy cosmetic products always provide good relationships with } \\
\text { customers }\end{array}$ & 10 & 20 & 30 \\
\hline 2 & $\begin{array}{l}\text { Pixy cosmetic products have a strong brand so the customers } \\
\text { trust them. }\end{array}$ & 8 & 22 & 30 \\
\hline 3 & $\begin{array}{l}\text { The reason consumers buy pixy cosmetic products is that they } \\
\text { trust the reviews of Youtuber and Key Opinion Leader, } \\
\text { RiriePrams. }\end{array}$ & 18 & 12 & 30 \\
\hline 4 & $\begin{array}{l}\text { The reason consumers buy Pixy cosmetic products is the } \\
\text { company that has good relationships with consumers. }\end{array}$ & 9 & 21 & 30 \\
\hline
\end{tabular}

Source: Preliminary Observation Results of Research (2019)

Based on the pre-survey result, it provides that most of the respondents answered "No" to the statements submitted. For the first question "Pixy cosmetic products always provide a good relationship with customers" as many as 10 respondents said "Yes" and as many as 20 respondents said "No. For the second question "Pixy cosmetic products make consumers believe in the Pixy brand" as many as 8 respondents answered "Yes" and as many as 22 respondents answered "No. For the third question "The reason consumers buy Pixy cosmetic products is that they believe in the reviews of Youtuber and Key Opinion Leader, RiriePrams", as many as 18 
respondents answered "Yes" and as many as 12 respondents answered "No". In the fourth question "The reason consumers buy Pixy cosmetic products is the company has a good relationship with consumers" as many as 9 respondents answered "Yes" and as many as 21 respondents answered "No". This means that the E-CRM and Brand Trust built by Pixy are still unable to increase Satisfaction and Loyalty towards Pixy's products. So based on this, the researcher felt the need to conduct research related to the influence of E-CRM, Brand Trust, on Customer Satisfaction and Loyalty on Pixy Products.

\section{LITERATURE REVIEW}

\section{E-CRM}

Customer-focused management of the entire e-business relationship with each customer, to measure, create and increase revenue and reduce costs for each customer $\&$ segment and thus to generate greater lifetime positive value (Michael, 2015: 1080).

According to Ab Hamid and McGrath (2005) the dimensions of E-CRM are as follows:

1) Information Quality Based on the information systems literature, the quality of information is a reflection of its relevance, up-to-dateness, adequacy, consistency, and understanding. As the efficiency of consumer decision-making improves when the search is simplified, the information presented on the site must be easy to understand and update. 2) Easy of Navigation, includes both the organization (format) of the layout content as well as easy-touse navigation (ease of use). The 14 site is easy to navigate and offers quick access to the information needed with minimal effort. 3) Customer Service Efficiency, Consumers constantly demand careful, continuous, and useful communication with company representatives. Since this attribute is often identified as a salient dimension of in-store selection behavior, company representatives must have the basic technical knowledge and skills to answer online questions. They must understand the specific needs of the consumer, can deal with problems as they arise, and address consumer complaints in a friendly manner.

\section{Brand Trust}

Chaudhuri and Holbrook (2001) argue that brand trust is defined as the willingness of consumers to rely on the brand's ability to follow the functions that the brand has shown. Brand Trust can be defined as the feeling of satisfaction and trust that consumers have in their communication with companies which is now commonly practiced by social media. One of the main goals to build brand trust is to achieve a competitive advantage and thus develop company performance (Khadim, et al. al, 2018: 3).

According to Delgado (2004), the dimensions of Brand Trust are:

\section{1) Brand Reliability}

Based on consumer confidence that the product can meet the promised value or in other words the perception that the brand can meet needs and provide satisfaction. Brand reliability is essential for creating trust in a brand because the brand's ability to meet the value it promises will make consumers feel confident about getting what is needed in this case the need to get out of feeling threatened. 


\section{2) Brand Intention}

Based on consumer belief that the brand can prioritize the interests of consumers when problems in product consumption arise unexpectedly. Both components of brand trust rely on subjective consumer assessments or are based on each consumer's perception of the benefits that the product/brand can provide.

\section{Customer Satisfaction}

According to Kotler (2000), customer satisfaction is the result felt by buyers who experience the performance of a company that matches their expectations (Dadang, 2010, p. 38). According to Zeithaml et al. (2009: 120), customer satisfaction can be divided into two, namely the satisfaction of each customer interacting with the provider or every Moment of truth or service encounter and second from the accumulation of each moment of truth or service encounter. From this, it can be interpreted that customer satisfaction can be felt both in every interaction process and after finishing consuming a good or service.

According to Irawan (2004: 37), there are five main dimensions of customer satisfaction, namely:

\section{1) Price}

For sensitive customers, usually low prices are an important source of satisfaction because they will get a high value for 10 money. This price component is relatively insignificant for those who are not pricing sensitive.

\section{2) Service Quality}

Service quality depends on three things, namely systems, technology, and people. Customer satisfaction with service quality is usually difficult to imitate because the formation of attitude and behavior that is in line with the company's wishes is not an easy job. Improvement must be carried out starting from the recruitment process, training, and work culture.

\section{3) Product Quality}

Customers feel satisfied after buying and using the product if the product quality is good.

\section{4) Emotional Factor}

Shown by consumers on the satisfaction they get in using a product/service that creates a sense of pride and self-confidence.

\section{5) Efficiency}

Ease of obtaining these products or services and ease of payment can make customers more satisfied if it is relatively easy, comfortable, and efficient to get a product or service 


\section{Loyalty}

According to Sutisna (2003: 41), loyalty is a pleasing attitude towards a brand which is presented in a consistent purchase of that brand all the time. Meanwhile, Fandy Tjiptono (2000: 110) states that customer loyalty is a customer commitment to a brand, store, supplier based on a very positive attitude and is reflected in consistent repeat purchases. Customer loyalty is a behavioral drive to make repeated purchases and to build customer loyalty to a product/service produced by this business entity takes a long time through a repetitive purchasing process (Gibson, 2005: 75). The customer is said to be loyal or loyal if the customer shows regular buying behavior or there is a condition that requires the customer to buy at least twice in a certain time interval. Efforts to provide satisfaction are made to influence customer attitudes, while the concept of customer loyalty is more related to behavior than customer attitudes (Griffin, 2005: 46).

According to Griffin (2005) the dimensions of Loyalty are as follows:

1) Makes regular repeat purchase (make repeat purchases regularly)

2) Purchase across product and service lines (purchase other product lines from your company)

3) Refers to others (provide references to others)

4) Demonstrates immunity to the pull of the competition (shows immunity to the pull of a competitor or is not easily influenced by the persuasion of competitors).

\section{Conceptual Framework}

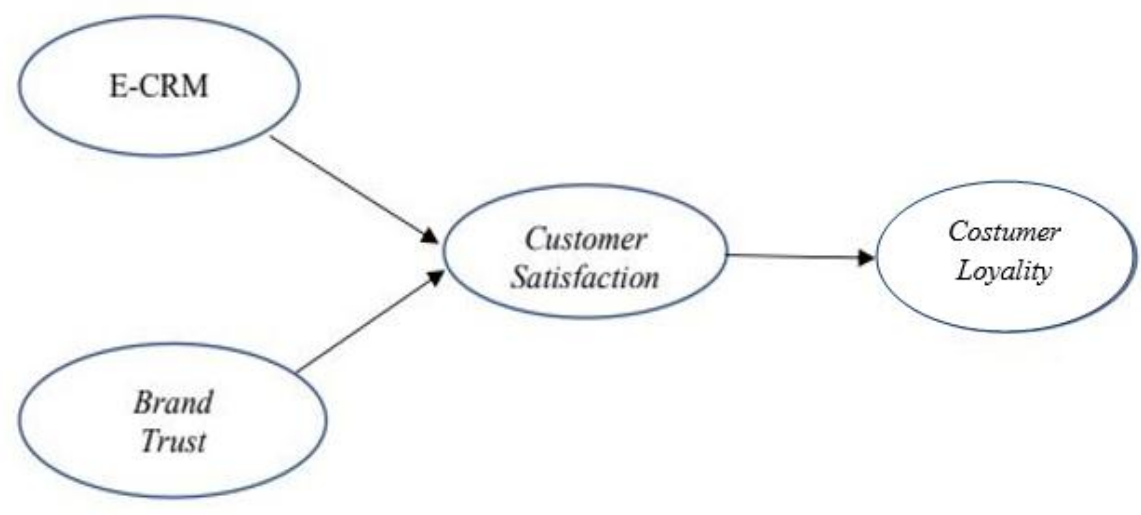

Figure 1. Conceptual Framework

\section{Hypotheses}

Based on the theoretical framework, the research hypotheses proposed in this study are as follows:

H1: E-CRM has a positive effect on Customer Satisfaction

H2: Brand Trust has a positive effect on Customer Satisfaction

H3: Customer Satisfaction has a positive effect on Loyalty 


\section{RESEARCH METHODS}

This research uses a descriptive type of research with a quantitative approach, namely research that only describes situations or events. This study does not seek or explain relationships, does not test hypotheses, or make predictions (Roswita, 2015). Descriptive research in this research is intended to get a description and information about the effect of ECRM, Brand Trust, and Customer Satisfaction on Loyalty.

This very large and diverse population cannot be known with certainty, as for the determination of the sample size in this study using the Rao Purba formula in Sujarweni (2015: 69) :

$$
n=\frac{Z^{2}}{4(M o e)^{2}}
$$

Information:

$$
\mathrm{n}=\text { Sample Size }
$$

$\mathrm{Z}=1.96$ at a certain level of significance $(90 \%$ confidence level $)$ Moe $=$ Margin of error, the maximum error rate is $10 \%$

By using the formula above, the following calculations are obtained:

$$
n=\frac{(1,96)^{2}}{4(10 \%)^{2}}=96,04=96
$$

The sampling technique in this study uses simple random sampling techniques or what is commonly referred to as simple random techniques.

This research also uses Path Analysis. According to Robert D. Retherford (1993) Path analysis is a technique for analyzing causal relationships that occur in multiple regression if the independent variable affects the dependent variable not only directly but also indirectly. David Garson of (North Carolina State University: 2003) defines path analysis as a regression extension model used to test the alignment of a correlation matrix with two or more causal models being compared by researchers. In its current development, path analysis has been expanded and deepened into the form of "Structural Equation Modeling" analysis or known as SEM. Structural Equation Modeling (SEM) is a causal model analysis of the independent (exogenous) variable, the intermediate variable (endogenous), the dependent variable (endogenous), and all unmeasured variables. This immeasurable variable is called a latent variable which is measured through its indicators (which consists of component components and each component consists of items). In SEM, there are two components, namely the structural model and the formation of latent variables. 


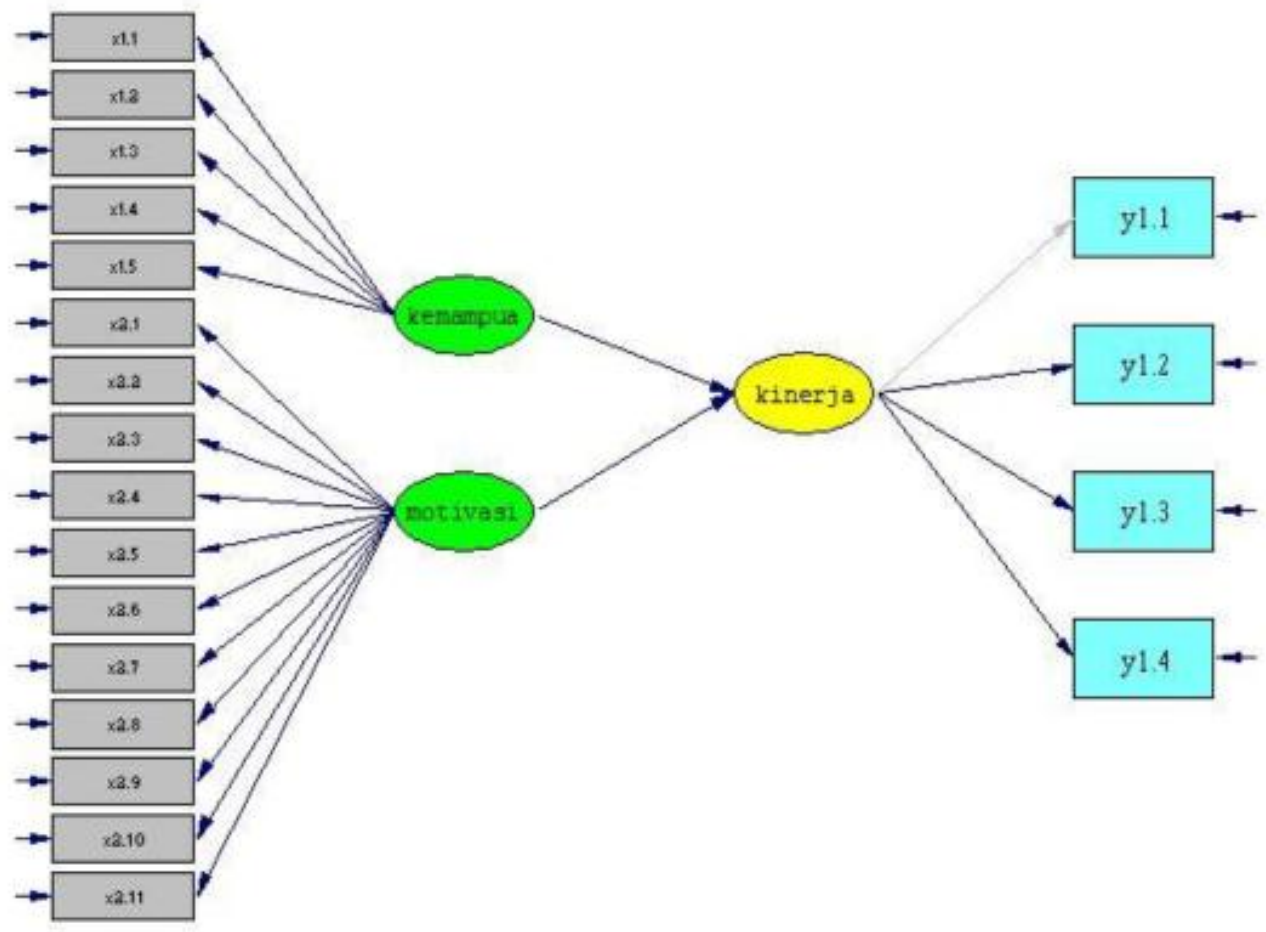

Figure 2. Structural Equation Modeling Research

\section{RESULTS AND DISCUSSION}

\section{A. Demographic Characteristic of Respondent}

Table 2. Demographic Characteristics of Respondents

\begin{tabular}{|c|c|c|c|}
\hline No. & Description & $\begin{array}{c}\text { Frequency } \\
\text { (People) }\end{array}$ & $\begin{array}{c}\text { Percentage } \\
(\%)\end{array}$ \\
\hline \multirow{3}{*}{1} & Gender & & \\
\hline & - Female & 64 & 66.67 \\
\hline & - Male & 32 & 33.33 \\
\hline \multirow{5}{*}{2} & Age & & \\
\hline & - Below 15 years old & 9 & 9.38 \\
\hline & - Between 15 - 20 years old & 40 & 41.67 \\
\hline & - Between 21 - 25 years old & 31 & 32.29 \\
\hline & - More than 25 years old & 16 & 16.67 \\
\hline 3 & Lama Menjadi Pengguna Pixy & & \\
\hline
\end{tabular}




\begin{tabular}{lll}
\hline$-<1$ year & 56 & 58.33 \\
$->1$ year & 40 & 41.67 \\
\hline
\end{tabular}

Source: Researchers' Analyzed Primary Data (2020)

Based on Table 2, the characteristics of the 96 respondents who are customers who use Pixy Products are:

a. Based on the gender of the respondents, the majority of respondents were female, that is, 66\%. This is because, for women, cosmetic products have always been a part of everyday life, to get and maintain beauty from time to time. Also, the decision of women to buy cosmetics is that makeup helps women increase self-confidence, women feel that makeup is their place to be creative and show their identity, the use of makeup as a way to look more perfect, and the demands of work are often one of the reasons for women. must dress up. Besides that, the trend also has an important role in women's habit of using makeup.

b. Based on the age of the respondents, the majority of respondents were between 15 and 25 years old, which is $73 \%$. This is because in the productive age range and at this age respondents are aware of the impact of premature aging due to the many activities carried out outside the home such as sports, going to school, meetings, work, and others. There is a risk of making skin patches and burning due to sun exposure. To keep protecting the skin from the sun, women are starting to look for makeup that suits their skin condition.

c. Based on the length of time being a Pixy user, the results processed by Pixy respondents are $58 \%$ new consumers who have used it for less than 1 year and $42 \%$ of old consumers who have used it for more than 1 year. Where Pixy must maintain and increase brand trust and Electronic Customer Relationship Management so that consumers become loyal to Pixy products.

The overall model fit test is made to find out how well the resulting model describes the actual conditions. Research data processing was carried out using the maximum likelihood method which was carried out with the Lisrel 8.80 application. The results of processing this data produce goodness of fit which can be seen in Table 3.,

Table 3. Research Model Fit Test Results

\begin{tabular}{lcccc}
\hline \multirow{2}{*}{\multicolumn{1}{c}{ Goodness Of Fit }} & \multicolumn{2}{c}{ Match Size } & \multicolumn{2}{c}{ Match Result } \\
\cline { 2 - 3 } & Good Fit & Marginal Fit & & \\
\hline Normed Chi-Square $\left(\chi^{2} / \mathrm{df}\right)$ & $<2.0$ & 1.551 & Fit \\
$\begin{array}{l}\text { Root Mean Square Error } \\
\text { (RMSEA) }\end{array}$ & $<0.08$ & 0.076 & Fit \\
$\begin{array}{l}\text { Root Mean Square } \\
\begin{array}{l}\text { Residual (RMR) } \\
\text { Goodness of Fit Index }\end{array}\end{array}$ & $\geq 0.90$ & $0.70<0.90$ & 0.74 & Fit \\
\hline
\end{tabular}


(GFI)

Fit

Normal Fit Index (NFI)

$0.80-<0.90$

0.96

Fit

Non-Normed Fit Index

(NNFI)

$\begin{array}{llll}0.90 & 0.80-<0.90 & 0.98 & \text { Fit }\end{array}$

Comparative Fit Index

(CFI)

$\geq 0.90 \quad 0.80-<0.90 \quad 0.98 \quad$ Fit

Increamental Fit Index

(IFI)

$\geq 0.90 \quad 0.80-<0.90 \quad 0.98 \quad$ Fit

Relative Fit Index (RFI)

$\geq 0.90 \quad 0.80-<0.90 \quad 0.95$

Fit

\section{Source: Researchers’ Analyzed Primary Data with LISREL (2020)}

From Table 3, it can be seen that the model fit value shows a good value, namely good fit and marginal fit, which means that the overall value of the fit shows a good fit. Figures 3 . and 3. represent the results of the overall model testing as follows:

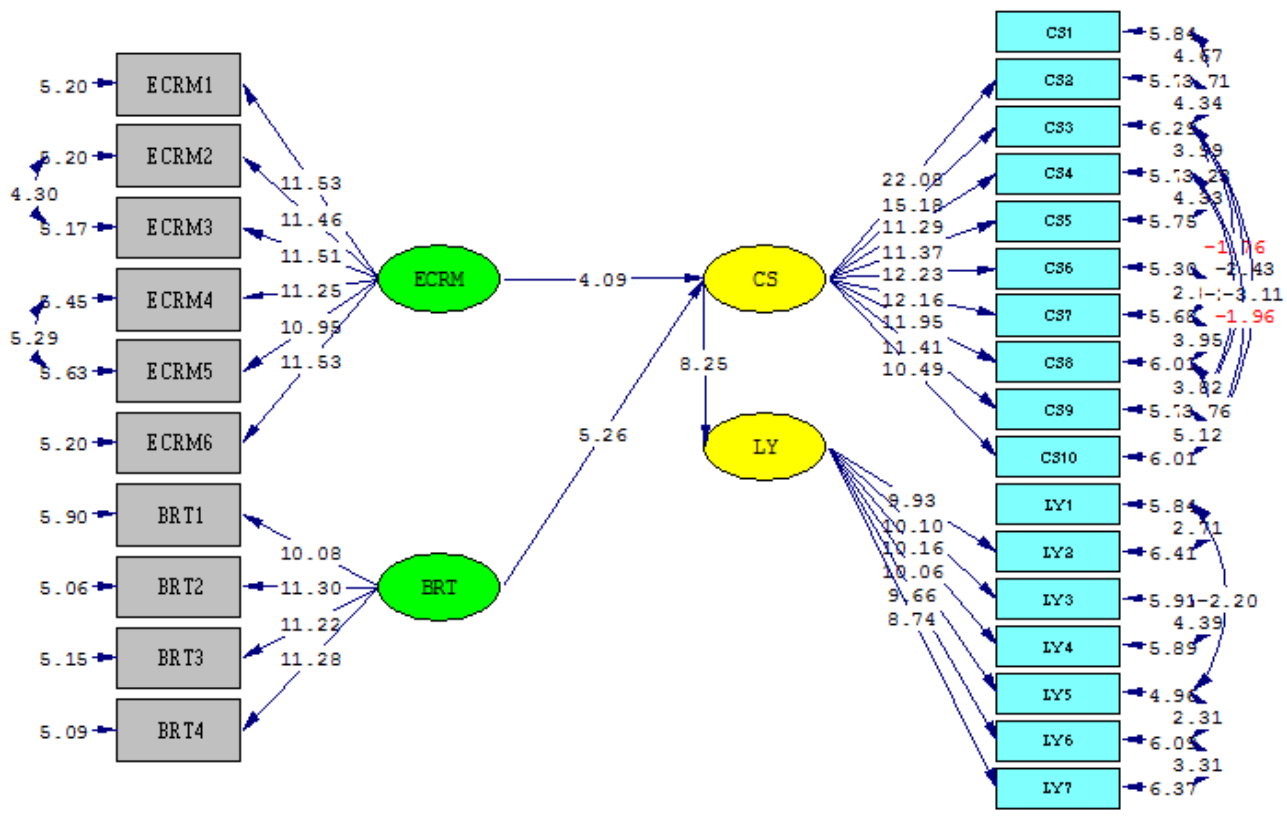

Figure 2. Overall Standardized Solution Model 


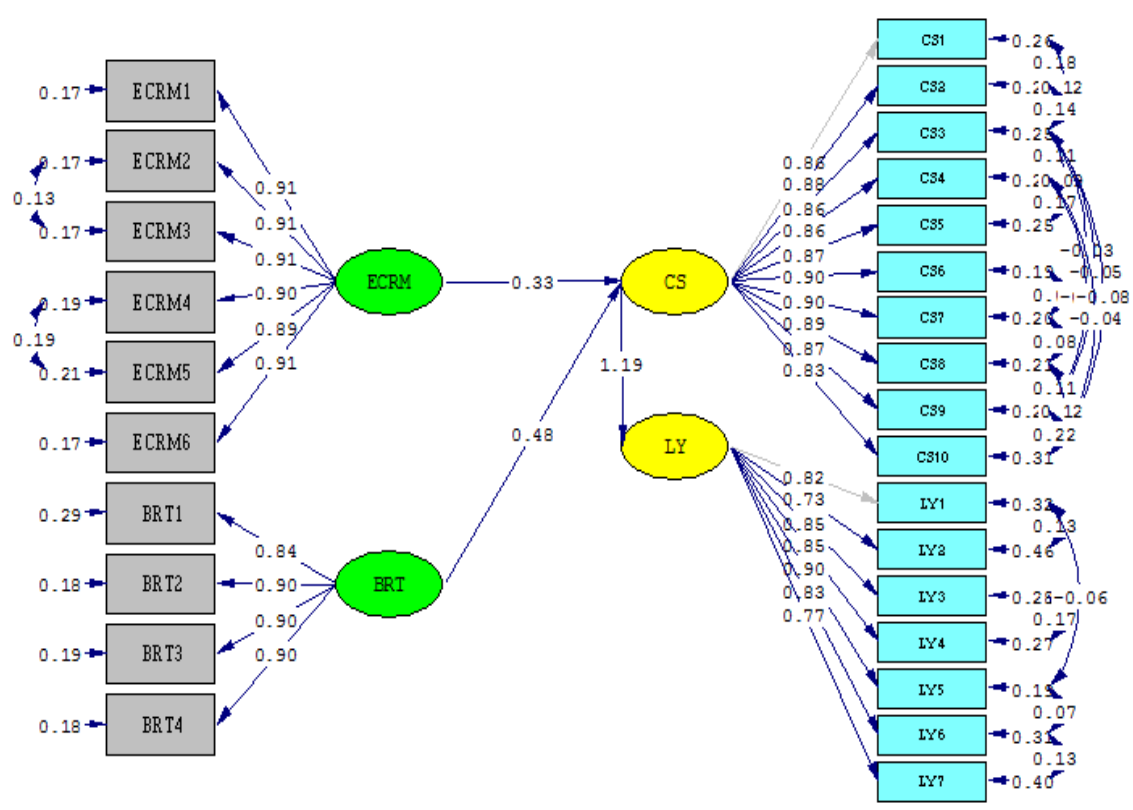

Chi-Square $=458.95, \mathrm{df}=296, \mathrm{P}$-value $=0.00000, \mathrm{RMSEA}=0.076$

Source: Researchers' Analyzed Primary Data with LISREL (2020)

Figure 3. Overall Standardized T-Value

\section{B. Measurement Model Test}

The validity test uses the Factor Analysis model. In this test, it is necessary to pay attention to the Standardize Loading Factor (SLF) value. Questions will be considered valid if they have SLF and Extraction values greater than 0.5 .

The reliability test shows the extent to which a measuring instrument can provide relatively the same results when re-measured on the same object. Reliability is calculated by the Variance Extract and Construct Reliability formula with the formula:

Construct Reliability Formula :

$$
\text { Construct Reliability }=\frac{\left(\sum \text { Standardized Loading }\right)^{2}}{\left(\sum \text { Standardized Loading }\right)^{2}+\sum e j}
$$

Variance Extract Formula:

$$
\text { Variance Extract }=\frac{\sum \text { Standardized Loading }}{2}
$$

The greater the value of the calculation results, indicating that the constituent indicators for a latent variable are reliable indicators of measuring these latent variables. The suggested construct reliability value is greater than 0.7 . Meanwhile, the recommended measure of variance extract feasibility is greater than 0.5 . 


\section{Validity and Reliability Test \\ a. E-CRM Construct Analysis}

In this test, 6 indicators were observed from E-CRM that had been tested, as follows:

Table 4. Validity and Reliability Construct E-CRM

\begin{tabular}{|c|c|c|c|c|c|}
\hline \multirow{2}{*}{$\begin{array}{c}\text { Kode } \\
\text { Indikator }\end{array}$} & \multirow{2}{*}{ SLF } & \multirow{2}{*}{$\begin{array}{c}\text { Standard } \\
\text { Errors }\end{array}$} & \multicolumn{2}{|c|}{ Reliability } & \multirow{2}{*}{ Keterangan } \\
\hline & & & $\mathrm{CR}>0,70$ & $\mathrm{VE}>0,5$ & \\
\hline ECRM1 & 0.74 & 0.11 & \multirow{6}{*}{0.96} & \multirow{6}{*}{0.82} & Valid \\
\hline ECRM2 & 0.74 & 0.11 & & & Valid \\
\hline ECRM3 & 0.72 & 0.10 & & & Valid \\
\hline ECRM4 & 0.71 & 0.12 & & & Valid \\
\hline ECRM5 & 0.66 & 0.12 & & & Valid \\
\hline ECRM6 & 0.76 & 0.11 & & & Valid \\
\hline
\end{tabular}

Standardized Loading Factor, ${ }^{(2)}$ Construct Reliability, ${ }^{(3)}$ Variance Extracted

Source: Researchers' Analyzed Primary Data (2020)

The results of data processing analysis Table 3.3. shows that the indicators forming latent variables (constructs) show good validity, namely the value of standardized loading factor $(\mathrm{SLF}) \geq 0.50$. The value of construct reliability (CR) E-CRM 0.96 is greater than 0.70 and the variance extracted (VE) value of 0.82 is greater than 0.50 which indicates that each indicator forming latent variables has good reliability.

\section{b. Brand Trust Construct Analysis}

In this test, 4 indicators were observed from the brand trust that had been tested, as follows:

Tabel 5. Reliability and Validity Construct of Brand Trust

\begin{tabular}{|c|c|c|c|c|c|}
\hline \multirow{2}{*}{$\begin{array}{c}\text { Indicator } \\
\text { Code }\end{array}$} & \multirow{2}{*}{ SLF } & \multirow{2}{*}{$\begin{array}{c}\text { Standard } \\
\text { Errors }\end{array}$} & \multicolumn{2}{|c|}{ Reliability } & \multirow{2}{*}{ Explanation } \\
\hline & & & $C R \geq 0,70$ & $\mathrm{VE} \geq 0,5$ & \\
\hline BRT1 & 0.59 & 0.14 & \multirow{4}{*}{0.94} & \multirow{4}{*}{0.79} & Valid \\
\hline BRT2 & 0.66 & 0.10 & & & Valid \\
\hline BRT3 & 0.65 & 0.10 & & & Valid \\
\hline BRT4 & 0.74 & 0.1 & & & Valid \\
\hline
\end{tabular}

Source: Researchers' Analyzed Primary Data (2020)

The results of data processing analysis Table 3.4. shows that the indicators forming latent variables (constructs) show good validity, namely the value of standardized loading factor $(\mathrm{SLF}) \geq 0.50$. The value of construct reliability $(\mathrm{CR})$ brand trust 0.94 is greater than 0.70 and the variance extracted (VE) value of 0.79 is greater than 0.50 which indicates that each indicator forming latent variables has good reliability.

\section{c. Customer Satisfaction Construction Analysis}

In this test, 10 indicators were observed from Customer Satisfaction that had been tested, as follows: 
Table 6. Reliability and Validity Construct of Customer Satisfaction

\begin{tabular}{lccccc}
\hline $\begin{array}{l}\text { Indicator } \\
\text { Code }\end{array}$ & \multirow{2}{*}{ SLF } & $\begin{array}{c}\text { Standard } \\
\text { Errors }\end{array}$ & $\mathbf{C R} \geq \mathbf{0 , 7 0}$ & VE $\geq \mathbf{0 , 5}$ & Explanation \\
\hline CS1 & 0.66 & 0.15 & & & Valid \\
CS2 & 0.68 & 0.10 & & Valid \\
CS3 & 0.62 & 0.13 & & Valid \\
CS4 & 0.66 & 0.10 & & Valid \\
CS5 & 0.66 & 0.14 & $\mathbf{0 . 9 7}$ & Valid \\
CS6 & 0.78 & 0.14 & & $\mathbf{0 . 7 8}$ & Valid \\
CS7 & 0.80 & 0.15 & & Valid \\
CS8 & 0.84 & 0.15 & & Valid \\
CS9 & 0.80 & 0.20 & & Valid \\
CS10 & 0.77 & 0.26 & & Valid \\
\hline \multicolumn{5}{c}{ Source: Researchers' Analyzed Primary Data (2020) }
\end{tabular}

Results of data processing analysis Table 3.5. shows that the indicators forming latent variables (constructs) show good validity, namely the value of standardized loading factor (SLF) $\geq 0.50$. The value of construct reliability (CR) Customer Satisfaction 0.97 is greater than 0.70 and the variance extracted (VE) value of 0.78 is greater than 0.50 which indicates that each indicator forming latent variables has good reliability.

\section{d. Loyalty Construction Analysis}

In this test, 7 indicators were observed from the loyalty that had been tested, as follows:

Tabel 7. Reliability and Validity Construct of Loyalty

\begin{tabular}{|c|c|c|c|c|c|}
\hline \multirow{2}{*}{$\begin{array}{c}\text { Indicator } \\
\text { Code }\end{array}$} & \multirow{2}{*}{ SLF } & \multirow{2}{*}{$\begin{array}{c}\text { Standard } \\
\text { Errors }\end{array}$} & \multicolumn{2}{|c|}{ Reliability } & \multirow{2}{*}{ Explanation } \\
\hline & & & $\mathrm{CR} \geq \mathbf{0 , 7 0}$ & $\mathrm{VE}>0,5$ & \\
\hline LY1 & 0.59 & 0.17 & & & Valid \\
\hline LY2 & 0.53 & 0.24 & & & Valid \\
\hline LY3 & 0.63 & 0.15 & & & Valid \\
\hline LY4 & 0.54 & 0.11 & 0.94 & 0.68 & Valid \\
\hline LY5 & 0.67 & 0.10 & & & Valid \\
\hline LY6 & 0.63 & 0.18 & & & Valid \\
\hline LY7 & 0.61 & 0.25 & & & Valid \\
\hline
\end{tabular}

Source: Researchers' Analyzed Primary Data (2020)

Results of data processing analysis Table 3.6. shows that the indicators forming latent variables (constructs) show good validity, namely the value of standardized loading factor $(\mathrm{SLF}) \geq 0.50$. The loyalty construct reliability $(\mathrm{CR})$ value of 0.94 is greater than 0.70 and the variance extracted (VE) value of 0.68 is greater than 0.50 which indicates that each indicator forming latent variables has good reliability.

\section{CONCLUSION AND SUGGESTION}

\section{a. Conclusion}

Based on the data analysis and discussion described in the previous chapter, several research conclusions can be drawn as follows:

1) E-CRM variable has a positive and significant effect on Customer Satisfaction 
2) Brand Trust variable has a positive and significant effect on Customer Satisfaction

3) Customer Satisfaction variable has a positive and significant effect on Loyalty

\section{b. Suggestion}

By analyzing the research results, some suggestions that can be considered as an input for Pixy's management and subsequent researchers are as follows:

1. Advice for companies

PT. Mandom Indonesia Tbk, especially Pixy's management, must have big data for Indonesian consumers who use cosmetics from various brands so that they can analyze the needs of cosmetics such as what Indonesian consumers need and expect. In the E-CRM factor, respondents gave the lowest response regarding the completeness of the information provided by Pixy.

To overcome this, Pixy can evaluate the accuracy or relevance of the content of the Pixy website. Information on the Pixy website must have a clear message, complete information can help consumers and potential consumers in solving problems, such as consumers no longer hesitate to buy the Pixy product they want. Completeness of information can increase customer satisfaction.

In addition to the information dimension, the indicator with a low value is "On the official Pixy cosmetics website page, it has explained in detail about Pixy's cosmetic products" that management must start paying attention, improving and completing features in providing information to consumers or potential consumers by providing complete and complete information. details on each Pixy product, besides that the Pixy website can add Q\&A features in providing additional information about Pixy products, presenting content that can provide more information to consumers related to Pixy products in collaboration with more influencers making Pixy products known to many people without taking time long. Film actors, singers, directors, writers, bloggers, Youtubers, or even celebrities who take part in creating content that is relevant to Pixy's products and helps potential customers learn more about Pixy's products. So that it can generate interest to all consumers or potential customers who visit the Pixy website which has an impact on increasing website traffic and customer satisfaction and potential customers who have visited the Pixy website. In addition to providing special information through websites, consumer e-mail, social media such as Facebook, Instagram and Twitter, call centers, and personalization and instant messaging services such as Whatsapp, Line, Kakao Talk, Telegram and WeChat, so that customers can always be interested in using them. products from Pixy, passing a special message sent to consumers shows Pixy's concern for consumers, to maintain good relationships with consumers.

Furthermore, the navigation dimension, the indicator with a low value is the appearance of the Pixy website which is easy to understand, where Pixy's management must update the appearance of the website page which is more mobile-friendly because not all consumers and prospective kinsmen who access the Pixy website use a PC because most consumers and potential consumers will access it via a mobile phone which results in a different web page display, making Pixy's website easy to load or access on a mobile 
phone. Another important thing for an easy-to-understand web page is easy navigation, which makes it easier for incoming visitors to enter the next page. Pixy can add breadcrumbs which are effective visual aids to increase the ability to find the desired sections and pages on a Pixy website.

Pixy must increase brand trust, consumers and potential consumers because they don't like the formulation of the Pixy brand cosmetics, this needs to be reviewed in the ingredients for making Pixy products, especially beauty products, where the products produced by Pixy must withstand the tropical Indonesian climate. Because different countries have different climates as well as the product formulation, it must be different, it must be adapted to the different climates, weather, and skin conditions of the Indonesian people. This can increase the satisfaction of potential customers and consumers of Pixy products to remain loyal.

Besides, consumers feel that the Pixy brand has not met expectations of good product quality, Pixy must continue to improve and improve product quality to satisfy the ever-changing desires of consumers. Not only has cosmetic products that are popular for an affordable price should provide a quality product that is comparable to the price of the product. By educating potential consumers that Pixy products are cosmetic products that have health benefits that not all people know about. This will encourage buyers to continue to use Pixy products over new products from other brands and will expand the existing market to bring in more sales impacting the satisfaction and loyalty of Pixy consumers.

\section{REFERENCES}

Albari, \& Safitri, I. (2018). The Influence of Product Price on Consumers' Purchasing Decisions. Review of Interrogative Business and Economics Research, 328-337.

Almira Bintang Ramadhan, Andriani Kusumawati Rizki, Yudhi Dewantara, Peram E-CRM (Electronic Customer Relationship Management) Dalam Meningkatkan Kualitas Pelayanan (2016), Jurnal Administrasi Bisnis (JAB)|Vol. 40 No.1

Altekar, S., \& Keskar, A. (2014). A Study of the Factors Impacting the Buying Decision Process vis-à-vis Specified Consumer Durables in NOIDA. Journal of General Management Research, 111-123.

Aradhana Chadha (2015) : "Case study of Hotel Taj In The Context Of CRM And Customer Retention".

Arto Lindblom, Sami Kajalo and Lasse Mitronen (2016) : "Exploring the links between ethical leadership, customer orientation and employee outcomes in the context of retailing".

Ayaz Ahmed Chachar (2015) :"Impact of Customer Relationship Management Dimensions on Customer Outcomes : Evidence from Pakistan.

Aydin, G., Akdeniz, A., \& Taskin, C. (2014). The Role of Brand Trust on Parents' Purchase Intentions of Baby Care Products. Dogus Universitesi Dergisi, 165-180.

Bader M. A. Almohaimmeed (2017) : "Restaurant Quality and Customer Satisfaction".

Bashar Ahmed, M.L. Ben Maati, Badreddine Al Mohajir (2015) : The Effectiveness Of The Intelligence E-CRM Application In Enhancing Positive Customer Relationships.

Bang Nguyen, Sharifah Faridah Syed Alwi, Sulaiman Ali (2017) :The Importance of Ethics in Branding: Mediating Effects of Ethical Branding on Company Reputation and Brand Loyalty".

Bilgihan, Anin (2016) : Gen Y customer loyalty in online shopping: An integrated model of trust, user experience and branding.

Bilgili, Ozkul, Koc, dan Oguz (2019) : “An Investigation Of Augmented Reality Applications From The Perspectives Of Brand Trust And Purchase Intentions Of Customers". 
Carol Lu, Celine Berchoux, Michael W. Marek, and Brendan Chen (2015) : Service quality and customer satisfaction: qualitative research implications for luxury hotels.

Chao Chin Huang (2017) : "The impacts of brand experiences on brand loyalty: mediators of brand love and trust". Chung, Yerim., Kim, Alex Jiyoung (2019) : Effects of mergers and acquisitions on brand loyalty in Luxury Brands: The moderating roles of luxury tier difference and social media. Journal of Business Research.

Daheshti, M., Firouzjah, J., \& Alimohammadi, H. (2016). The Relationship between Brand Image and Brand Trust in Sporting Goods Consumers. Annals of Applied Sport Science, 27-34.

Didin Hadi Saputra, Dian Utami Sutiksno, Aditya Halim Perdana Kusuma, Romindo, Romindo, Dewi Wahyuni, Agung Purnomo, Janner Simarmata (2020). Digital Marketing: Komunikasi Bisnis Menjadi Lebih Mudah, Yayasan Kita Menulis.

Dongwon, Lee Junghoon., Moon, Yong., Jin Kim Mun Y.Y (2014) : Antecedents and consequences of mobile phone usability: Linking simplicity and interactivity to satisfaction, trust, and brand loyalty

Foster, B. (2016). Impact of Brand Image on Purchasing Decision on Mineral Water Product "Amidis" (Case Study on Bintang Trading Company). American Research Journal of Humanities and Social Sciences, 1-11.

Hong Zhang, Kem Z.K.Zhang, Matthew K.O. Lee, Feng Feng (2015) : Brand loyalty in enterprise microblogs Influence of community commitment, IT habit, and participation".

Huang Chien-Jung (2017) : Relational Benefits, customer satisfaction, and Customer Citizenship Behaviour in Chain Store Restaurant.

Kalakota, Ravi \& Maria Robinson. 2000. e-Business 7.0 : A Roadmap to Success. Addison Wesley, Longman Inc., USA.

Khadim, R., Hanan, M., Arshad, A., \& Saleem, N. (2018). Revisiting Antecedents of Brand Loyalty: Impact of Perceived Social Media Communication with Brand Trust and Brand Equity as Mediators. Academy of Strategic Management Journal, 1-13.

Khoza, K., \& Harjati, L. (2012). Analisis Brand Trust dan Brand Royalty Konsumen Garuda Indonesia. WIDYA, 41-48.

Khuong, M., \& Duyen, H. (2016). Personal Factors Affecting Consumer Purchase Decision towards Men Skin Care Products A Study in Ho Chi Minh City, Vietnam. International Journal of Trade, Economics and Finance, 44-50.

Lahindah, L., Merisa, \& Siahaan, R. (2018). The Influence of Product Innovation and Service Quality to Buying Decision and the Impact to Repeat Buying at Progo Road Bandung. The Asian Journal of Technologi Management, 118-124.

Mang'unyi, E., Khabala, O., \& Ghovender, K. (2017). The relationship between e-CRM and customer loyalty: a Kenyan Commercial Bank case study . Business Perspectives, 106-115.

Mang'unyi, Khabala, Ghovender (2017) : Bank Customer Loyalty and Satisfaction: The Influence of Virtual E-CRM".

Murtiningsih, D., Moeljadi, Noermijati, \& Rofialty. (2016). The Effect of Brand Trust and Brand Loyalty (Studies in the University of Budi Luhur Jakarta). International Journal of Business, Economics and Law, 57-61.

Muhammad hassan, Arlslan Rafi dan Syed Sibtain Kazmi (2016) : "Impact of differentiated customer service, brand trust, brand commitment and brand salience on brand advocacy".

Mustafeed Zaman, Laurent Botti and Tan Vo Thanh (2016) : "Does managerial efficiency relate to customer satisfaction? The case of Parisian boutique hotels".

Naggar, R. (2017). The Impact of Experience and Brand trust on Brand loyalty, while considering the mediating effect of brand Equity dimensions, an empirical study on mobile operator subscribers in Egypt. The Business and Management Review, 16-25. 
Pratiwi, D., Saerang, D., \& Tumewu, F. (2015). The Influence of Brand Image, Brand Trust and Customer Satisfaction on Brand Loyalty (Case of Samsung Smartphone). Jurnal Berkala Ilmiah Efisiensi, 377-385.

Pribanus Wantara (2015) : "The Relationships among Service Quality, Customer Satisfaction, and Customer Loyalty in Library Services".

Rifai, A., \& Wahyudi. (2016). The Effect to Create Customer Engagement on Customer E-Banking. Jurnal Dinamika Manajemen, 191-205.

Riorini, S., \& Widayati, C. (2015). Relationship Commitment dan Customer Engagement: Stimulus serta Konsekwensi pada Konsumen Pengguna Transportasi Darat. Jurnal MIX, 418-436.

Risitano, M., Romano, R., Sorrentino, A., \& Quintano, M. (2017). The impact of consumer-brand engagement on brand experience and behavioural intentions. British Food Journal, 1884-1896.

Romla, S., \& Ratnawati, A. (2018). Keputusan Pembelian E-Commerce melalui Kemudahan Penggunaan, Kualitas Informasi dan Kualitas Interaksi Layanan Web. EKOBIS, 59-70.

Roswita, 2015. Motif dan Kepuasan Penggunaan Media Sosial di Kalangan Pelajar Siswa SMA Negeri 5 Samarinda. E-Journal Komunikasi, Vo.3, No.3, pp. 290-301.

Rubio, Natalia., Vilasenor, Nieves., Yague, Maria Jesus (2016). Creation of consumer loyalty and trust in the retailer through storebrands: The moderating effect of choice of store brand name. Journal of Retailing and Consumer Services, 358- 368.

Sanaji, E. (2015). Pengaruh Customer Engagement terhadap Kepuasan Pelanggan dan Kepercayaan Merek serta Dampaknya pada Loyalitas Merek. Journal of Research in Economics and Management, 246-261.

Silalahi, U. (2012). Metode Penelitian Sosial. Bandung: Refika Aditama.

Sugiyono. (2012). Metode Penelitian Pendidikan, Pendekatan Kuantitatif, Kualitatif, dan $R \& D$. Bandung: Alfabeta.

Vivek, S. (2009). A Scale of Consumer Engagement. Dissertation.

Wiranti, M., \& Nugraha, H. (2017). Analisis Strategi Customer Engagement terhadap Loyalitas pada PT. Nascomoco Magelang. Jurnal Ilmu Administrasi Bisnis, 1-10.

Yoong, L., \& Lian, S. (2019). Customer Engagement in Social Media and Purchase Intentions in the Hotel Industry. International Journal of Academic Research in Business and Social sciences, 5468.

Zlatko Bezhovski, Fida Hussain (2016). The Benefits of the Electronic Customer Relationship Management to the Banks and their Customers. Research Journal of Finance and Accounting, 114- 115 .

Zulaicha, S., \& Irawati, R. (2016). Pengaruh Produk dan Harga terhadap Keputusan Pembelian Konsumen di Morning Bakery Batam. Jurnal Inovasi dan Bisnis, 125-136.

Zyminkowska, K., Zyminkowski, T., \& Blaszczyk, R. (2017). Effects of Customer Engagement Behavior. Journal of Economics and Management, 134-154. 